\title{
POLSKA Z ODDALI W PISARSTWIE WSPOMNIENIOWYM JANA NOWAKA-JEZIORAŃSKIEGO
}

\author{
Konrad W. TATAROWSKI (Lódź)
}

Na aksjologicznym horyzoncie świata Jana Nowaka-Jeziorańskiego ojczyzna zajmowała miejsce naczelne.

W moim domu rodzinnym tradycje patriotyczne były bardzo żywe - mówił w wywiadzie, którego udzielił w ostatnich latach życia. — W moim dziecinnym pokoju wisiał sztych Kościuszki i sztych Poniatowskiego. Nie wiem, w jakim stopniu dzisiaj na przykład Trylogia wpływa na ludzi, ale my wychowaliśmy się na Sienkiewiczu, który budził w nas niesłychanie mocne uczucia patriotyczne ${ }^{1}$.

Do tego doszły, wpojone w dzieciństwie zasady „Dekalogu”, wywiedziona z zasad katolicyzmu tolerancja, przywiązanie do reguł demokracji, w której mogą współistnieć antagonistyczne, ścierające się ze sobą koncepcje — na przykład dwu wielkich wizjonerów politycznych i konkurentów do sprawowania władzy w międzywojennej Polsce. Oto jak ich oceniał Nowak:

Dmowski i Piłsudski, grając na dwóch różnych fortepianach, w gruncie rzeczy dążyli do jednego celu i świetnie się wzajemnie uzupełniali. Powtórzę: ich drogi były zupełnie inne, łączył ich natomiast cel, co w rezultacie przyniosło niepodległość ${ }^{2}$.

Krąg tych podstawowych wartości składa się na obraz — przywołując terminologię Stanisława Ossowskiego ${ }^{3}$ — „prywatnej ojczyzny”, która pozostaje w ścisłym związku ze sposobem pojmowania i stosunkiem jednostki do „ojczyzny ideologicznej”, a zatem do obszaru zamieszkałego przez naród i ujętego w organizacyjne ramy państwowości. Ojczyzny prywatnej i zarazem ideologicznej bronił „Kurier z Warszawy”.

\footnotetext{
${ }^{1}$ J. Nowak-Jeziorański, Polska z bliska, Kraków 2005, s. 10.

${ }^{2}$ Tamże, s. 39.

${ }^{3}$ S. Ossowski, O ojczyźnie i narodzie, Warszawa 1984, s. 26.
} 
A potem, już jako uchodźca polityczny, w obliczu utraty „ojczyzny ideologicznej”, czyli niepodległego państwa polskiego, podjął walkę o jego odzyskanie. Nie przez nawoływanie do czynu zbrojnego - bo ten skazany byłby na klęskę (o czym wiedział po traumatycznym doświadczeniu powstania warszawskiego), ale poprzez ratowanie samoświadomości narodowej i przeciwdziałanie procesom sowietyzacyjnym.

Jan Nowak należał do generacji, która zmuszona została przez historyczny bieg dziejów do dokonywania „twardych” wyborów. Ich stawką było życie — w znaczeniu zupełnie dosłownym:

Całe moje życie wojenne to łańcuch cudownych ocaleń — powie po latach Miałem fantastyczne szczęście, w przeciwieństwie do straszliwie przetrzebionego przez wojnę mojego rocznika, kolegów szkolnych, akademickich ${ }^{4}$.

Alternatywą walki z okupantem hitlerowskim, a potem stalinizmem była zdrada, kolaboracja albo rezygnacja (,emigracja wewnętrzna”) - całkowite wycofanie się z życia publicznego i utrata możliwości wpływu na bieg zdarzeń. „Trzecią drogę”, którą po wojnie wybrało wielu intelektualistów w kraju, opisał Czesław Miłosz w Zniewolonym umyśle — drogę „,ketmana”, uległości i dyspozycyjności, przy zachowaniu (zapewne jedynie pozorów) wewnętrznej niezależności.

Jeziorańskiemu, podobnie jak innym uchodźcom politycznym, podobne dylematy nie były dane. Każdy z nich nosił w sobie obraz ,prywatnej ojczyzny”, który w żaden sposób nie przystawał do narzuconego przemocą kształtu niesuwerennego państwa („ojczyzny ideologicznej”). I nie musiał tego faktu ukrywać czy kamuflować. Pozostał jednak problem sposobu odniesienia się do owej nowej rzeczywistości politycznej w Polsce po 1945 roku, a zwłaszcza do komunistycznej władzy rządzącej krajem. I tutaj, w różnych środowiskach emigracyjnych, pojawiły się istotne różnice — od postulatu całkowitego i całościowego zerwania wszelkich kontaktów z reżimem aż po, widoczne zwłaszcza po październiku 1956 roku, próby nawiązywania nieformalnych kontaktów z niektórymi jego przedstawicielami i pośredniego oddziaływania na polityczne decyzje ośrodków władzy w PRL.

$$
* * *
$$

Słowo „Polska” należy do pojęć kluczowych w literaturze wspomnieniowej i publicystyce Jana Nowaka-Jeziorańskiego. Wystarczy przypomnieć tytuły jego książek: Polska droga ku wolności ${ }^{5}$, Polska pozostała soba ${ }^{6}$, Polska z oddali ${ }^{7}$, Rozmowy o Polsce ${ }^{8}$, Polska wczoraj, dziś i jutro ${ }^{9}$, Polska z bliska ${ }^{10}$ i na koniec opracowana przez Dobrosławę Platt Polska droga do NATO ${ }^{11}$ — imponujące świadectwo determinacji i działań, podejmowanych przez Nowaka na różnych szczeblach amerykańskiej administracji w imię zapewnienia Polsce bezpieczeństwa i należnego jej miejsca w strukturach zachodniej demokracji. Używając metafory, można by powiedzieć, że romans

\footnotetext{
${ }^{4}$ J. Nowak-Jeziorański, Polska z bliska, s. 15.

${ }^{5}$ Tenże, Polska droga ku wolności 1952-1974, Londyn 1974.

${ }^{6}$ Tenże, Polska pozostata sobq, Londyn 1980.

${ }^{7}$ Tenże, Polska z oddali. Wojna w eterze - wspomnienia t. 2: 1956-1976, Londyn 1988.

${ }^{8}$ Tenże, Rozmowy o Polsce, Warszawa 1995.

${ }^{9}$ Tenże, Polska wczoraj, dziś i jutro, Warszawa 1999.

${ }^{10}$ Tenże, Polska z bliska, Kraków 2003.

11 Tenże, Polska droga do NATO. Listy, dokumenty, publikacje, wybrała. i oprac. D. Platt, Wrocław 2006.
} 
z Polską był dla autora wymienionych książek dozgonnym sakramentem, wyzwaniem, aktem wiary, nadziei i miłości. Kiedy pod koniec życia odpowiadał na pytanie: „Co z perspektywy lat postrzega Pan jako najważniejsze w życiu?”, odpowiedział:

Mieć misję i cel... Wiedzieć, po co się żyje, po co pracuje, po co ryzykuje. Mieć cały czas poczucie, że służy się swojemu powołaniu, które jest sprecyzowane i wiadomo na czym polega. To najważniejsze... ${ }^{12}$.

Wierność owemu ,powołaniu” towarzyszyła mu zapewne już wtedy, kiedy wraz ze swoją żoną „,z goryczą i smutkiem w duszy” stali w rozradowanym tłumie na Piccadilly Circus w Londynie w dniu zwycięstwa nad Niemcami. Rozpoczynał się emigracyjny rozdział w ich życiu, ponad półwieczny okres oglądania „Polski z oddali”. W owym dniu tryumfu Kurier z Warszawy nie czuł się zwycięzcą. Zapisał wtedy tę myśl: „Można przegrać bitwę, a nawet wojnę, lecz ocalić naród" "'. Wydaje mi się, że to może być klucz do zrozumienia późniejszych poczynań Nowaka — już w okresie kierowania Głosem Wolnej Polski RWE. Ocalenie narodu — w sytuacji utraty państwowości — było zadaniem nadrzędnym. Misją do wykonania.

„Misja” — to droga, ,cel” — to horyzont, ku któremu się zmierza. Horyzont — wolna i niepodległa Polska — w owym czasie, w okresie stalinizmu i zimnej wojny, był czymś odległym i zgoła abstrakcyjnym. Chyba, że ktoś rokował nadzieje w wybuchu kolejnej wojny światowej. Jeziorański nie był zwolennikiem tego sposobu myślenia ${ }^{14}$. Pozostało zatem ratowanie substancji narodowej, walka z komunistyczną ,pierekowką dusz”. Prowadzenie „wojny na idee”, wojny w eterze. Narzędzie — rozgłośnię radiową — dostał dzięki realizacji amerykańskiego pomysłu powołania Komitetu Wolnej Europy. Jak go używał jako dyrektor Głosu Wolnej Polski, jaką wybrał drogę do realizowania swojej misji, opisuje w swoich radiowych wspomnieniach, które — w odróżnieniu od wcześniejszego Kuriera $z$ Warszawy — w sposobie konstrukcji materiału narracyjnego odbiegają od klasycznych wzorców pamiętnikarstwa.

$$
* * *
$$

Różne bywają pamiętniki, szczere i podfarbowane, pretensjonalne i proste, opisowe i psychoanalityczne, czyli egocentryczne. Materiał jest obfity, można więc mnożyć te podziały, dzieląc je przede wszystkim zasadniczo na warte czytania i różnego gatunku makulaturę

— tymi zdaniami, które uznać można za wstęp do definicji genologicznej, ambasador Edward Raczyński rozpoczął świetnie napisaną Przedmowę do Kuriera $z$ Warszawy ${ }^{15}$. I dodaje:

Pamiętnik Jana Nowaka należy bezwzględnie do tych, których przeoczyć nie wolno. Dotyczy spraw dla każdego Polaka najistotniejszych i mówi o nich otwarcie, bez zabezpieczania się przed krytyką z tej lub innej strony.

${ }^{12}$ Tenże, Polska z bliska, s. 38 .

${ }^{13}$ Tenże, Kurier z Warszawy, Kraków 2005, s. 435.

14 „Spora część powojennej emigracji z Andersem na czele wiązała swe nadzieje z nieuniknionym, jak się zdawało, wybuchem konfliktu. Nie należałem do niej. Konfrontacja zbrojna oznaczała atak atomowy na sowieckie szlaki komunikacyjne biegnące przez Polskę. W trzeciej wojnie światowej sojusznikiem Zachodu byłyby Niemcy. Polska mogła wyłonić się z niej nie tylko całkowicie zniszczona, ale okrojona raz jeszcze do wymiarów państwa szczątkowego"; J. Nowak-Jeziorański, Wojna w eterze, Kraków 2000, s. 94.

${ }^{15}$ E. Raczyński, Przedmowa, [do:] J. Nowak-Jeziorański, Kurier z Warszawy, s. 7-8. 
Wskazuje też na bogate zaplecze dokumentacyjne oraz literackie walory narracji w omawianej książce:

W opisywanych epizodach Jan Nowak jest jedną z osób działających — obok mężczyzn i kobiet, studentów, robotników i kolejarzy — wprowadza ją w tok opowiadania jak gdyby z zewnątrz, każąc czytelnikowi domyślać się swoich przeżyć wewnętrznych i patriotycznego uniesienia, które dla niego jak i dla wszystkich żołnierzy tej armii było źródłem siły. Opisy poszczególnych, indywidualnych i zbiorowych wyczynów - jak pierwsza wyprawa autora do Szwecji albo lot brytyjską dakotą nad polanę pod Tarnowem - są pasjonujące. Przebieg wydarzeń oddał szczegółowo jak w najlepszym dreszczowcu. Im prostsze zaś są słowa opisu, tym bardziej wzruszająca jest aura, która tę opowieść osnuwa.

W Kurierze z Warszawy obraz autora zarysowany jest wyraziście. Pierwszoosobowa narracja — rozwijana od 1 stycznia 1976 roku $^{16}$ do Niedzieli Palmowej, 3 kwietnia 1977 roku $^{17}$ w alpejskiej miejscowości Pass Thurn — rekonstruuje, zgodnie z kanonami gatunkowymi pamiętnikarstwa ${ }^{18}$, portret autora (od wczesnego dzieciństwa po dzień zakończenia II wojny światowej) na szerokim tle społecznym, kulturalnym, politycznym. Przynosi też oceny minionych zdarzeń, czasem zapewne kontrowersyjne, formułowane przez autora po latach, w czasie spisywania wspomnień. Dominuje jednostkowy, subiektywny punkt widzenia w sposobie opisywania zdarzeń, ludzi i miejsc. Warstwa dokumentacyjna, często przywoływana przez autora (i dołączona do książki w postaci aneksu), ma jedynie ów obraz mocniej osadzić w historycznych realiach, a oceny i opinie narratora wzmocnić i uwiarygodnić.

Kuriera $z$ Warszawy Nowak-Jeziorański pisał po upływie ponad trzydziestu lat od zakończenia działań wojennych. Jak czytamy w słowie Od autora przywoływanej pozycji:

Pamiętniki ogłaszane bezpośrednio po wypadkach wchodzą w zakres polityki. Pomijać w nich trzeba wszystko, co może dać bron do ręki wrogowi albo stanowi tajemnicę należącą do innych. Wspomnienia spisywane po latach są już tylko historią. Pisząc je nie szedłem na żadne kompromisy wobec ludzi żyjących albo sympatyków ludzi zmarłych. Chciałem przekazać tym, którzy przyjdą po nas, obraz możliwie pełny, tak jak sam go widziałem, aby z doświadczeń naszego pokolenia mogli wyciagnąć własne wnioski na przyszłość ${ }^{19}$.

Warto zapamiętać to rozróżnienie, które wprowadził Nowak ze względu na okres publikacji wspomnień — na pamiętniki, które wchodzą w zakres polityki, oraz te, które należą do historii. Wspomnieniowa dylogia byłego dyrektora Rozgłośni Polskiej RWE: Wojna $w$ eterze i Polska zoddali została wydana przed upadkiem komunizmu, w okresie funkcjonowania monachijskiej Rozgłośni. Pierwsza z wymienionych książek w 1986, druga w 1988 roku. Można więc założyć, iż autor pominął w nich to „,co może dać broń do ręki wrogowi albo stanowi tajemnicę należącą do innych".

O ile zatem Kuriera $z$ Warszawy można bez żadnych wątpliwości zaliczyć do kanonu klasycznego pamiętnikarstwa, to w przypadku radiowych wspomnień Nowaka-Jeziorańskiego można mieć pewne wątpliwości. Sam autor we wstępie do Wojny $w$ eterze określa swą książkę jako „osobiste wspomnienia splecione z kroniką histo-

\footnotetext{
${ }^{16}$ Zob.: J. Nowak-Jeziorański, Greta [w:] tegoż, Polska z bliska, s. 199.

${ }^{17}$ J. Nowak-Jeziorański, Kurier z Warszawy, s. 436.

18 N. Lehman, [hasło:] Pamiętnik [w:] Stownik rodzajów i gatunków literackich, red. G. Gazda i S. Tynecka-Makowska, Kraków 2006, s. 506-509.

${ }^{19}$ J. Nowak-Jeziorański, Od autora, [w:] tegoż, Kurier z Warszawy, s. 10.
} 
rycznych wydarzeń” ${ }^{20}$. Zaznacza też, iż „,Z konieczności pisałem nie tylko w pierwszej osobie, ale przede wszystkim o własnych poczynaniach i doświadczeniach"21. Dużo miejsca w jego radiowych wspomnieniach zajmuje dokumentacja, zwłaszcza częstokroć przywoływana i omawiana służbowa korespondencja z amerykańskimi zwierzchnikami, cytaty z prasy emigracyjnej, krajowej i zachodniej, listy wymieniane z licznym kręgiem znajomych z Polski i z Zachodu, fragmenty audycji radiowych (własnych i innych autorów), zapiski z dziennika Eugeniusza Romiszewskiego, etc.

W wielu partiach omawianych pozycji pamiętnikarską narrację pierwszoosobową zastępuje podmiot zbiorowy „Nasze audycje były dotychczas adresowane głównie do «wewnętrznej emigracji». Obecnie stanęliśmy wobec pytania, jak się odnieść do opozycji" 22 lub bezosobowy, zobiektywizowany tok rozważań, charakterystyczny dla publicystyki:

XX Zjazd KPZR, rehabilitacja KPP rozwiązanej w 1938 r., tajny referat Chruszczowa ujawniający cześć zbrodni Stalina, śmierć Bieruta - cały ten zespół wypadków był drugim po rewelacjach Światły potężnym katalizatorem procesów zachodzących w Polsce ${ }^{23}$.

Nowak-Jeziorański wymienionymi formami narracji posługuje się bardzo sprawnie, zestawia i przeplata je ze sobą — sobie często pozostawiając ostatnie słowo. Jest równocześnie uczestnikiem i obserwatorem wydarzeń, wykonawcą określonych zaleceń i ich współtwórca, dziennikarzem i strategiem, który kreśli scenariusze rozwoju sytuacji w kraju i na świecie, wyznaczając w nich kierowanej przez siebie rozgłośni radiowej określone miejsce.

Obowiązywała go podwójna lojalność - wobec słuchaczy w kraju i wobec amerykańskich właścicieli stacji. I choć nie było tu — przynajmniej w początkowym okresie działalności RWE - sprzeczności w pojmowaniu dalekosiężnych i strategicznych celów ideowych i politycznych, co zresztą Nowak wielokrotnie podkreślał - to na różnych etapach działalności RWE pojawiały się istotne rozbieżności w formułowaniu bieżących zadań oraz ich realizacji w praktyce antenowej. Obrona autonomii programowej stacji i zasady partnerstwa w relacjach $\mathrm{z}$ amerykańskimi zwierzchnikami była nadrzędnym celem dyrektora Rozgłośni Polskiej. Aby to osiągnąć stosował metody perswazji, umiejętnie przekonując amerykańskich partnerów do swoich racji albo nacisku, łącznie z groźbą dymisji i strajku całego zespołu polskiego w obliczu planów wprowadzenia cenzury prewencyjnej ${ }^{24}$.

RWE stała się też dość szybko - co ujawniło się w okresie odprężenia w polityce światowej po 1956 roku — swoistym narzędziem przetargowym w relacjach Stanów Zjednoczonych ze Związkiem Radzieckim, czy szerzej, między światem zachodnich demokracji a komunizmem. Na początku lat 70., w okresie działalności komisji Fulbrighta, Wolnej Europie groziła likwidacja ${ }^{25}$. Trudno ocenić, na ile dyplomatyczne zabiegi podejmowane przez Nowaka groźbę tę oddaliły — faktem jest, że je podejmował na tyle skutecznie, że został zaatakowany przez Fulbrighta na forum Senatu Stanów Zjed-

\footnotetext{
${ }^{20}$ J. Nowak-Jeziorański, Od autora, [w:] tegoż, Wojna w eterze, Kraków 2000, s. 5.

${ }^{21}$ Tamże.

${ }^{22}$ Tamże, s. 230.

${ }^{23}$ Tamże, s. 235.

${ }^{24}$ Zob. rozdział Przeciwko cenzurze w radiu Wolna Europa, [w:] Wojna w eterze, s. 318-337.

${ }^{25}$ Zob. rozdział Ofensywa na Bonn $i$ Waszyngton, [w:] Wojna w eterze, s. 606-622.
} 
noczonych $^{26}$. Przypominam to, by wskazać, że Jeziorański, by realizować na antenie swoje koncepcje programowe - musiał równocześnie działać na wielu frontach, pełnić rolę negocjatora i brać udział w rozgrywkach politycznych.

$\mathrm{Na}$ wsparcie w tych działaniach środowisk emigracyjnych — poza nielicznymi wyjątkami - liczyć nie mógł. Jeszcze przed rozpoczęciem emisji programu radiowego znalazł się w ogniu agresywnego ataku prawie całej prasy emigracyjnej i krajowej. Jak pisał w rozdziale $W$ obliczu nagonki:

Między prasą emigracyjną i komunistyczną rozgrywał się teraz dziwny ping-pong. Piłkę serwowaną z Londynu, Paryża czy Nowego Jorku podchwytywał skwapliwie przeciwnik. Pierwsze reżimowe ataki na rozgłośnię, która jeszcze nie powstała, były po prostu cytatami z prasy emigracyjnej ${ }^{27}$.

W późniejszym okresie działalności rozgłośni jej dyrektor stał się obiektem licznych prowokacji i akcji dezinformacyjnych PRL-owskiej bezpieki. Miały one zapewne pewien, choć nie decydujący wpływ, na decyzję Nowaka o przejściu na radiową emeryturę.

$* * *$

Pora przejść do rozwinięcia zagadnienia: jak autor Kuriera z Warszawy pojmował służbę wobec ojczyzny w warunkach emigracyjnych. Siłą rzeczy, z braku możliwości szerszego rozwinięcia i egzemplifikacji tego bardzo rozległego tematu, skupię się tu na paru kwestiach, w moim odczuciu kluczowych.

Pierwsza to stanowisko Nowaka wobec amerykańskiej „doktryny wyzwolenia” (jej gorzkie owoce zebrali Węgrzy w październiku i listopadzie 1956 roku), która stała u źródeł powołania Radia Wolna Europa. Autor Wojny $w$ eterze rozwija szeroko ten temat w rozdziale Polityka powstrzymywania czy wyzwolenia ${ }^{28}$. Rzecz sprowadza się do pomysłu wprzęgnięcie RWE jako jednego z koni pociaggowych do rydwanu ,zimnej wojny" - z nie do końca sprecyzowanymi planami zakończenia sowieckiej okupacji w krajach Europy Środkowo-Wschodniej na drodze kolejnej wojny światowej bądź narodowych powstań. Jak pisał Jeziorański:

Sama myśli, że tragedia Powstania Warszawskiego mogłaby raz jeszcze powtórzyć się za naszego życia, budziła odruch gwałtownego i powszechnego sprzeciwu. Z własnego, gorzkiego doświadczenia świadka historii poznałem jedną z najniebezpieczniejszych słabości polskiego charakteru: skłonność do odrywania się od rzeczywistości i łatwość, z jaką fałszywe nadzieje zamieniały się w samozapalny materiał wybuchowy. Matką złudzeń dla Polaków zawsze była wyolbrzymiona wiara w Zachód ${ }^{29}$.

W przygotowanych przez Nowaka założeniach programowych dla Głosu Wolnej Polski żadnych dwuznaczności w tej materii nie było. W przedstawionych zespołowi polskiej sekcji w marcu 1952 roku ,politycznych zasadach programu” znalazły się między innymi następujące punkty:

— Nie będziemy usiłowali sprawować „rządu dusz” w Polsce. Emigracja jest częścią narodu, ale nie może nim zdalnie kierować. Polska jest nad Wisłą, a nie Tamizą, Sekwaną czy Wezerą. Radio ma służyć społeczeństwu, nieść mu pomoc;

${ }^{26}$ Zob. rozdział Akcja specjalna. Falsyfikat w rękach Fulbrighta, [w:] Wojna w eterze, s. 623-648.

${ }^{27}$ J. Nowak-Jeziorański, Wojna w eterze, s. 59.

${ }^{28}$ Tamże, s. 89-106.

${ }^{29}$ Tamże, s. 95. 
— [...] Mamy podtrzymać opór moralny i niezależną myśl. Będziemy wystrzegali się wszystkiego, co mogłoby pchnąc społeczeństwo do oporu czynnego albo organizowania się pod ziemią;

- Radio musi być odbiciem różnorodnych, nawet sprzecznych opinii i ocen, bo różnice poglądów najbardziej przekonująco demonstrują wolność słowa. Będziemy podtrzymywali tradycje wszystkich głównych nurtów politycznych, ale nie będzie w naszych programach wzajemnych napaści ani ataków personalnych;

— Każdy ma prawo do swoich poglądów, ale w sprawach zasadniczych, takich jak niepodległość, demokracja, granice, jesteśmy zgodni i solidarni $[\ldots]^{30}$.

O realizację tych założeń - przedstawionych również w emocjonalnym, ale rzeczowym przemówieniu inauguracyjnym w dniu otwarcia działalności Głosu Wolnej Polski (3 maja 1952) - Nowak-Jeziorański dbał z żelazną konsekwencją. Dochodziło zresztą na tym tle do ostrych sporów z amerykańskimi zwierzchnikami w RWE ${ }^{31}$. Ale efekt antenowy był znakomity, o czym świadczy depesza Ambasady USA w Warszawie przesłana Departamentowi Stanu dwa miesiące po inauguracji działalności monachijskiej Rozgłośni:

Potwierdzone informacje wskazują ostatnio, że audycje nadawane przez RWE do Polski spotykają się z entuzjastycznym przyjęciem ludności. Częste wypowiedzi RWE, że angażowanie się w zbrojny opór $w$ jakiejkolwiek formie byłoby narażaniem własnego bezpieczeństwa bez celu, wywierają dobre wrażenie na Polakach. Mówi się także $\mathrm{z}$ aprobata o częstych ostrzeżeniach radia przed wojenną histerią. Informatorzy namawiają by programy tego rodzaju często powtarzać, bo mnoży się ostatnio liczba ludzi biorących udział w organizacjach podziemnych i wielu Polaków wierzy, że wojna wisi na włosku. Słuchacze w Polsce są zdziwieni ilością dokładnych informacji o bieżącej sytuacji w audycjach $^{32}$.

Najbardziej dramatycznym sprawdzianem przyjętej przez Nowaka polityki programowej były wydarzenia października 1956 roku. W obliczu nowej sytuacji — przypomnijmy ją za autorem Wojny w eterze:

Już w piątek, dziewiętnastego października, gdy nadeszła rewelacyjna wiadomość o lądowaniu sowieckiej delegacji, stało się jasne, że Moskwa znalazła się po raz pierwszy w ostrym, jawnym konflikcie z PZPR, a ściślej mówiąc z częścią polskiego kierownictwa partyjnego ${ }^{33}$

— podjął on decyzję udzielenia pełnego poparcia tym elementom w kierownictwie PZPR, które stały się przedmiotem ataku. Jak czytamy dalej: „Natychmiastowy zwrot W naszych audycjach polegał przede wszystkim na radykalnej zmianie tonu, którą słuchacz musiał z miejsca zauważyć" ${ }^{34}$. Węgierska sekcja RWE, która przyjęła puste hasła ,polityki wyzwolenia” za dobrą monetę, wybrała w owych dniach zupełnie inną strategię ${ }^{35}$. Jak to się skończyło, wszyscy wiemy, co oczywiście nie oznacza, że rozgłośnia węgierska ponosi całą odpowiedzialność za tragedię powstania węgierskiego. $\mathrm{W}$ wymiarze antenowym oznaczało to jednak dla niej utratę wiarygodności.

${ }^{30}$ Tamże, s. 55.

${ }^{31}$ Zob. m.in. podrozdział Przeciw amerykańskim wytycznym, [w:] Wojna w eterze, s. 119-122.

32 J. Nowak-Jeziorański, Wojna w eterze, s. 83-84.

${ }^{33}$ Tamże, s. 262.

${ }^{34}$ Tamże.

${ }^{35} \mathrm{Na}$ ten temat zob. rozdział Radio Wolna Europa wobec tragedii węgierskiej, [w:] Wojna w eterze, s. 274-296, a także: G. R. Urban, Rok 1956 przemyślany, [w:] Radio Wolna Europa $i$ walka o demokrację. Moja zimna wojna w czasach zimnej wojny, Warszawa 2000. 
Wraz z upadkiem powstania węgierskiego ,polityka wyzwolenia” została wykreślona ze słownika politycznego Stanów Zjednoczonych. Zastąpiono ją pojęciem ,gradualizmu", oznaczającym popieranie stopniowej liberalizacji systemów komunistycznych w Europie Środkowo-Wschodniej.

Nowak-Jeziorański założenia owej polityki realizował już wcześniej. O „nowej taktyce RWE" dyskutował z zespołem Głosu Wolnej Polski już wiosną 1956 roku $^{36}$. Zwracał wtedy między innymi uwagę na ujawnienie się w kraju w okresie przed październikowej „odwilży” opozycji, której trzon stanowili intelektualiści partyjni oraz ludzie, nie będący komunistami, ale nie wierzyli w wojnę, wyzwolenie i możliwość pozbycia się rządów komunistycznych. „Ujrzeli natomiast — pisał — perspektywę przekształcenia modelu, uczynienia go bardziej ludzkim, znośniejszym, dopuszczającym mały margines wolności i uczestnictwa czynnika społecznego"37. Wskazywał też, że oprócz zasadniczego podziału przebiegającego między rządzącymi komunistami a społeczeństwem istnieje też linia podziału, która przebiega $\mathrm{w}$ poprzek partii ${ }^{38}$. W związku z tym konieczne było uzupełnienie radiowego programu o dodatkowe treści. Jak proponował w wytycznych, przedstawionych zespołowi redakcyjnemu, należało:

zaopatrzyć intelektualistów w amunicję, dostarczając im informacji, naświetlenia i oceny wydarzeń w Polsce, w ZSRR i w innych krajach ujarzmionych oraz przekazując im reakcje Zachodu na te wydarzenia ${ }^{39}$.

$$
* * *
$$

Cała późniejsza działalność Nowaka-Jeziorańskiego w Rozgłośni Polskiej RWE była konsekwencją przyjętych w owym okresie założeń ideowych i politycznych. W radiowej praktyce owo, można by chyba powiedzieć — pragmatyczne — nastawienie, stawianie na liberalizacyjne przekształcenia wewnątrz partii rządzącej PRL, budziło pewne wątpliwości w zespole redakcyjnym i poza nim. Świadectwem tego był spór Nowaka z Leopoldem Tyrmandem, który omawiałem w czasie konferencji w Białymstoku w 2007 roku („Emigracyjny spór o «prawo do nawrócenia» i jego konsekwencje”).

Ciekawego materiału do refleksji dostarcza też korespondencja z Janem Kottem, znajdująca się w archiwum Nowaka-Jeziorańskiego w Ossolineum. Tam też odnalazłem wielostronicowy stenogram z narady redakcyjnej z 4 marca 1957 roku (Nowak pisze o niej krótko w rozdziale Narada redakcyjna w drugim tomie swoich radiowych wspomnień $^{40}$ ). Jest to dokument świadczący, z jednej strony o ogromnym zaangażowaniu Jeziorańskiego w wydarzenia toczące się w kraju, o jego wyczuleniu na wszelkie objawy odchodzenia przez PZPR od linii października i na zagrożenia z tego faktu płynące - z drugiej zaś o tym, jak bezwzględnie narzucał swój punkt widzenia pozostałym dziennikarzom rozgłośni (zwłaszcza komentatorom politycznym), sprowadzając ich zadania do ról informacyjnych i odtwórczych. Jak mówiła w czasie owej narady Aleksandra Stypułkowska:

Co jest największą bolączką? Wycenienie, określenie, które z naszych powiedzeń, których używamy w naszych skryptach jest niebezpieczne [...] my ciągle mówimy „ko-

\footnotetext{
${ }^{36}$ Zob. podrozdział Dwa dni rozmyślań, [w:] Wojna w eterze, s. 230-231.

37 Tamże, s. 231.

${ }^{38}$ J. Nowak-Jeziorański, Wojna w eterze, s. 233.

${ }^{39}$ Tamże, s. 232.

${ }^{40}$ Tamże, s. 311-312.
} 
mentarz". To co my robimy to nie są komentarze. To są, właściwie nie ma na to określenia - to są rodzaje raportów [...] to jest, w każdym razie praca odtwórcza, przetwórcza ${ }^{41}$.

Nie ulega wątpliwości, że Jan Nowak nie był szefem, który szedł za głosem opinii kierowanego przez siebie zespołu. Dobrze zapamiętał radę udzieloną mu przez Adama Ciołkosza na początku radiowej drogi:

Byłem w moim życiu — powiedział - żołnierzem, dowódcą kompanii, byłem parlamentarzysta, redaktorem, publicystą. Zawsze broniłem demokracji, ale niech pan pamięta: dwie funkcje życia zbiorowego nie znoszą kolektywnego kierownictwa dowodzenie mniejszą czy większą formacją wojskową oraz redagowanie gazety albo kierowanie radiostacją ${ }^{42}$.

Nie ulega jednak również wątpliwości, że kierował się dobrem ogółu, że był wierny swoim przekonaniom i starał się służyć z niezwykłą konsekwencją i pełną determinacją narodowi i ojczyźnie.

41 Konferencja - Sytuacja $w$ Polsce, $4^{\text {th }}$ March 1957, Archiwum Jana Nowaka-Jeziorańskiego — Zakład Narodowy im. Ossolińskich, sygn. 28/99/1, s. 60.

${ }^{42}$ J. Nowak-Jeziorański, Wojna w eterze, s. 50. 